\section{Reconfiguring Periphery: Localizing Spatial Dependencies of Capitalism in West Asia and \\ North Africa}

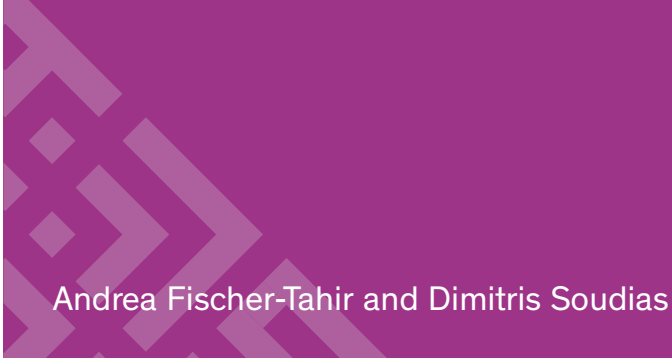

Keywords: MENA; Space; World-System Theory; Resistance; Knowledge; Capitalism; Periphery

\section{Crossing Through the Fields}

Aden, May 2007: Southern Yemenis take to the streets by the thousands to voice their anger about insufficient pensions and forced retirement to the central government in Sanaa. Sidi Bouzid, December 2010: the suicide of a young street vendor sparks local unrest in a medium-scale town, leading to the Tunisian Revolution. Dara'a, March 2011: massive protest against political and economic injustice unfolds in the Syrian medium-scale town, marking the beginning of an uprising that eventually evolved into a civil war.

On an empirical level, people in all of these places react to the experiences and fears of increasing poverty and social marginalization. In the first example, the context is a unified state in which the inhabitants of a former socialist-ruled territory in the south became dependent on the political, economic and cultural decisions of the centralized government in the north (Augustin). In the second example, the Tunisian regime and its political and economic elites pursued a "selective redistribution of resources" that resulted in "the acute and systematic marginalization of the southern, central and western regions, as opposed to the concentration of wealth and power in the north and the east of the country" (Ayeb 486-87). As for the Syrian case, popular unrest started in a part of the country that has been ignored by Bashar al-Assad's neoliberal development policies. The upheaval has been interpreted as a popular reaction to the violation of a social contract that "was based on the state's provision of social welfare and development in exchange for the population's renunciation of political participation" (Ruiz de Elvira and Zintl 330).

Therefore, on an analytical level, these cases exemplify how spatial disparities and spatially manifested social injustice lead to forms of resistance. They indicate that the inner peripheries in the countries addressed here are products of unequal resource and revenue distribution, as well as of specific capital investment policies. This META issue turns its focus to "periphery." Conceptually speaking, we do not conceive peripheries to be places that are localized on the "natural" margins of a particular regional, national or global entity. Neither do we consider them to be essentialized and unchangeable. Instead, we assume that peripheries are manifestations of spatial differentiation. They are processual in that they emerge, transform and sometimes even disappear through 
complex economic and political processes, through demographic reconfigurations and through changes in socio cultural norms and values.

Take the term "Middle East" for example. This neologism originated in English between 1900 and 1902, ${ }^{1}$ arising from the political and military imperative of demarcating the region between the "Near East" (at the time denoting the Ottoman Empire including the Balkans), and the "Far East" (which referred to China). These regional depictions are based on a view of the world with Europe at its center. The "Mid dle East" is therefore constituted as inherently peripheral to Europe, not merely as a depiction, but especially with regards to unequal power relations in terms of economic exploitation, and the spatial "othering" (in terms of socio-cultural norms and values) of this area and its people. It is for these reasons with relation to our conceptual assumptions about "periphery" that we decided to use the less-Eurocentric terms of West Asia and North Africa as geographic labels. ${ }^{2}$

With this in mind, we broadly define "periphery" alongside Andrea FischerTahir and Matthias Naumann as spatially materialized "inequality of power relations and access to material and symbolic goods that constructs and perpetuates the precedence of the centers over areas that are marginalized" (18).

This approach is influenced by depen dency theory and world-system theory (WST), both of which have been devel oped by scholars of the global North and South alike. Scholars such as Raúl Prebisch and André Gunder Frank, and later Immanuel Wallerstein, Samir Amin or Dieter Senghaas acknowledged that cap italist modes of production hold the world in a tight grip. In situating their analyses on a global scale, they suggest that the world became divided into "cores" or "centers" and "peripheries" and "semi-peripheries." While the former are centers of capital accumulation and concentrated political power, the latter are dependent on those centers, but they will eventually transform in one way or another into "developed" societies. Drawing on this paradigmatic approach, generations of researchers have investigated the societies of the South in terms of manifestations of unequal power distribution, dependencies and developmental transformations in their relations to the North. Feminist scholars in particular have highlighted the gender dimension of the capitalist penetration of the South and forms of neocolonialism (Ward; Blumberg; Mies) whereas neo-Marxists were in search of the revolutionary subject, which they-at least partly-have identified in the "marginalized" of the earth (Kay; Quijano).

Embedded in the matrix of global economy, the "center-periphery" conceptualization found its way into the academic study of West Asia and North Africa. In approaches based on political economy, this concept came to challenge the rentier state debate that was so dominant in the study of the region. ${ }^{3}$ Some works explored the "center-periphery" distinction in contexts where central governments sought to "discipline" minority groups at the geographical margins (Entessar). Others applied the approach to any form of power negotiation between central and peripheral actor groups in conflictual configurations (Schetter and Glassner; Wedeen). Dependency theory and WST are also echoed in more recent debates on the ongoing processes of social and political transformation in West Asia and North Africa, especially with regards to urban-rural disparities and inner urban spatial differentiation (Fischer-Tahir Bouziane, Harders, and Hoffmann). ${ }^{4}$ In this latter trend, different academic discourses and fields overlap. The heritage of dependency theory and WST meets the "spatial turn" in the humanities and social sciences, which is closely linked to the work of Michel Foucault and Henri Lefebvre as well as to Anglophone critical 
geographers such as David Harvey, Neil Smith or Doreen Massey. In the study of West Asia and North Africa, researchers seemingly take for granted that "[we] do not live, act and work 'in space' so much as by living, acting and working we produce space" (Smith 85). Drawing on Foucault, it became a matter-of-course to discuss power and governmentality in their structured and structuring relation to space. In addition, researchers appropriated Lefebvre's spatial triad of perceived conceived and lived space. The experienced materiality of space production involves political decision-making, practices of capital investment, and built infrastructure. The representation of space is being organized by the means of scientific and technocratic symbols, concepts or maps. Lived space, finally, refers to practices of negotiating norms, values, lifestyles and identities, and takes into account signifying practices and experience in everyday life (Lefebvre 33). Translating this triad into a methodological tool, territories labeled "peripheral" can be grasped in a more systematic way.

Our focus on "periphery" is also a response to the dominant patterns of investigating the so-called Arab Spring and the current wars, which are so dramatically affecting the lives of millions in West Asia and North Africa. Researchers tend to explain events in the spaces of violence through such notions as religion, ethnicity, communaritarism, tribalism, or authoritarianism. More recently, debates have even pathologized empirical observations and have made use of the catchphrase "trauma"-a concept that originally traveled from the fields of medicine and psychoanalysis to the humanities and social sciences. ${ }^{5}$

While it is not our intention to completely abandon established patterns of conflic description, we do seek to turn the debate towards approaches that are more grounded in political economy. Therefore we suggest discussing "periphery," and the various ways in which people cope with and resist marginalization, in their relation to capitalism. In doing so, we draw on Neil Smith and his suggestion that certain territories become neglected and disconnected from "development"-as is shown in this META issue's case studies on Southern Yemen, central Tunisia and southern Syria-not because these are remote areas but because of particular politics of capital investment. Smith termed this process "uneven development," which he conceived not as some sort of misapplication of best-practice capitalist development policies, but rather as an intrinsic feature of the capitalis modes of production grounded in the inherent contradictions of capitalism. In the antagonistic relationship between capital and labor (and similarly between center and periphery) for example, what makes the capitalist rich makes the worker poor and vice versa. In this configuration, the capitalist has the interest to continue exploitation and the worker the interest to stop exploitation. This conflict is manifested in disciplinary techniques imposed on workers as well as their practices of resistance. Equally contradictory, capital must be constantly invested in built environments in relatively fixed and enduring ways. Yet, it also needs to remain mobile in order to be able to circulate properly. The concentration and de-concentration of capital creates "see-saw movements" (Smith 152).

It is for these contradictions that uneven development occurs, leading to spatial differentiation and the creation of peripheral spaces. These processes can be identified on various scales: global, regional, national, or local-the latter of which may point to urban fragmentation. However, these systematic scales are, in "reality," much more interrelated and overlapping. In this regard, Doreen Massey has pointed to the increasing global-local interdependencies of the "changing spatial organization of the relations of production and the division of labor" (38). Through these considerations, we seek to encourage scholars 
to re-think "periphery" as a product of a global-scale imagination (as created by dependency theory and WST) by means of finding ways to make these global-local interdependencies visible.

\section{Discussing "Peripheral Spaces" and "Periphery"}

This issue represents a collection of articles that provides conceptual thoughts and empirical research on spatial differentiation and dependencies. It is designed as a critical reflection on "periphery." Thus, the meta-article of this issue, written by Hartmut Elsenhans, sheds light on the historical journey of the notion of "periphery" and its antipode "center"/"core." He argues that this approach helps to meaningfully describe the positions within the international system, but criticizes that "center-periphery relations" do not explain why capitalism exists. With regard to West Asia and North Africa, he states that "underdevelopment" does not result from unfair resource transfer to global "centers" but rather from a lasting shortage of national food production and the "greed of Western capitalists, Arab rentier state classes and middle classes."

The significance of food production and spatialities of food insecurity do also matter in our anti/thesis section. Outlining recent spatialities of hunger and conflict in the region, Jörg Gertel takes a critica stance towards "center/periphery," pointing out their limited explanatory range. Instead of thinking in polarizing terms and territorially fixed nation-states, he advo cates approaches that investigate postnational configurations of food insecurity and the new temporal modes of actions that shape spaces of hunger.

Cilja Harders argues in favor of "center/ periphery" as a fruitful way of making asymmetric power relations visible. Yet the "over-deterministic" connotation attached to this notion, as well as the global scale inherent to the concept should be abandoned. Arguing from a feminist perspective on knowledge production, she suggests "provincializing" and "localizing" the core-periphery relations in order to highlight the agency of human actors.

Efforts to localize "periphery" is what al the authors of our articles in the focus section have in common. Anne-Linda Amira Augustin turns our attention to Southern Yemen. She discusses processes of change in the economy, demography, and political decision-making as well as in socio-cultural norms and values since the Yemeni unification and the subsequent war in 1994. Based on material from extensive field research, she highlights how the individual and collective experience of marginalization triggers discourses of independence.

Britta Elena Hecking provides the reader with insights into strategies of coping with social marginalization. Her local focus is the spatially fragmented city of Algiers, where she investigates the daily survival struggle of young street hawkers. These practices of "navigating," she concludes, must be interpreted as both preserving and challenging the status quo.

In a similar vein, Johannes Frische describes the practice of "getting by" in urban peripheries of contemporary Tunisia. Investigating how young street vendors narrate encounters with state agents such as the police, he highlights the ambivalent character of state-society relations, which become visible in form of negotiation, rather than in open protest. Katharina Lenner examines the making of peripheries in Jordan. Focussing on two sub-districts in the country's rural periphery, she shows how marginalization has unfolded over time and how it may further change due to shifts in national development politics. Her main concern is the discursive aspect of constructing and maintaining dependency. She suggests that "conceptualizations of peripheralization" need to engage more seriously with practices of "othering" as discursive forms in the making of peripheries. 


\section{Andrea Fischer-Tahir}

studied Arabic and Oriental philology, social anthropology, and studies of religions at the University of Leipzig, where she received her PhD in 2003 with a thesis on resistance and memory in Iraqi Kurdistan. She has long-standing research experience in the region and has also published on gender, media, knowledge production, and rural-urban dynamics. She became involved in civil society projects in Kurdistan, and her book, Brave Men, Pretty Women:

$\diamond$ Gender and Symbolic Violence in

- Kurdish Urban Society, was translated into Kurdish in 2011. Currently, she is a research fellow at the research network "Re-Configurations: History, Remembrance and Transformation Processes in the Middle East and North Africa" at Marburg University.

\section{email:}

andrea.fischertahir@staff.uni-marburg.de
Schluwa Sama sheds light on the transformation of the Kurdistan Region of Iraq from a former "periphery" into an "island" of international capital investment. Having been affected over decades by war and persecution, and neglected by the central regimes in terms of development, the cit ies of Erbil, Dohuk and Sulaimaniya are now going through neoliberal transformations. Here, Sama observes practices of business and of leisure in shopping malls, which embody ideas of "modernity" and "progress."

Our issue's focus on "periphery" concludes with a close-up article by Rachid Ouaissa. He reminds us of the work and life of Frantz Fanon, taking us back to the time the "core/periphery" concept was invented as an explanation for international dependencies. At that time, the concept underlined the need to resist against the spatially manifested injustice of colonialism and capitalism. Ouaissa stresse the influence that Fanon's work had on academic debates and political struggles, and he highlights Fanon's relevance for inquiring dependencies in today's era of neoliberal globalization.

Not spatial differentiation, but spatia exclusion and spatial control are themes of the two articles in the off-topic section Irene Fernandez Ramos discusses contemporary Palestinian theater in times of spatial closure and immobilization being imposed by the Israeli state. She shows how theater opens new spaces of representation, which allow for alternative and subversive narratives. Enrico Ille turns our attention to Sudan and political imprisonment. He discusses prison poetry as rep resentation of resistance against a political regime that fosters centralization and the homogenization of its subjects through the aid of political Islam.

In the review-section, Djene Bajalan reminds us of the Kurdish conflict with a reading of Jordi Tejel Gorgas' book La Question kurde: Passé et présent (2014)-a conflict that is closely linked to spatial mar ginalization and histories of spatial contro as a means of disciplining Kurdish rebels. Hanna AlTaher completes our issue in providing us with a very thoughtful reading of Haidar Eid's 'Worlding' (Post) Modernism: Interpretative Possibilities of Critical Theory. With Eid, she argues, research is only meaningful if it also serves the political purpose of critical intervention into relations of exploitation and dependencies.

\section{On Knowing and Knowledge}

All of this issue's authors provide critical reflections on "periphery," illustrating and exemplifying the term's analytical value and/or adding more content to the cur rent established corpus of ideas the term carries. Some put "periphery" into ques tion, criticizing its limited explanatory value and analytical range. In highlighting the making of "peripheries" as a struc tured and structuring structure-to borrow from Pierre Bourdieu-other authors draw from "peripheralization" as suggested by Fischer-Tahir and Naumann or on the "beyond the center" notion, by Hoffmann, Bouziane, and Harders, in order to stress the processual character of the concept.

Having carefully read and edited the articles, there are some striking observations regarding how "periphery" has been used throughout our issue. For most of the contributors "periphery" seems to be a research too/ that helps to grasp particular types of spatial differentiation. Relatedly but not the same, others name it a concept, in the sense of the German Begriff Throughout the articles, research tool and concept seem to have been used interchangeably with notion, approach or term. We may well interpret this empirical finding as a matter of taste and writing style. It would also be possible to consider it as an expression of conceptual multiplicity. But we could also say it is an indicator of representational uncertainty. To make it even more confusing, Cilja Harders suggests (albeit en-passant) dealing with "periphery" and "core/periphery" as a "metaphor" and Denkfigur, respectively. At first glance, 


\section{Dimitris Soudias}

is a research fellow in the BMBF-funded "Re-Configurations" project at the Center for Near and Middle Eastern Studies at Philipps University, Marburg. His recent publications include "Policing January 25 Protest, Tactics, and Territorial Control in Egypt's 2011 Uprising" (META-Journal 4, 2015), Negotiating Space: The Evolution of the Egyptian Street, 2000-2011 (The American University in Cairo Press, 2014), "Präsenz und Raum in der Arabischen Revolte" together with Christoph

¿ Schumann (Präsenz und Implizites

Wissen. Ed. Christoph Ernst and Heike Paul. transcript, 2013). His current work focuses on the role of space-making practices and protest experiences during the 2011 square occupations in Cairo and Athens.

email:soudias@uni-marburg.de labeling "periphery" as a figure of speech or a figure of thought and interpretationor put differently, as a corpus of ideas and meanings-may appear to be an invitation to conceptual ambiguity. But, is this helpful for making sense of the world? How can it accommodate our efforts to (want to) know?

Anthropologist, Fredrik Barth, understands knowledge as whatever "a person employs to interpret and act on the world." He takes knowledge as "a corpus of substantive assertions and ideas of the world," which exists through "social relations" and must be "instantiated and communicated in (...) media as a series of partial representations in the form of words" (3). Barth's approach makes it possible to distinguish between different forms of knowledge (e.g., religious, political, scientific, everyday life-based, profession-related) without hierarchizing academic and sciencebased technological knowledge at the top and everyday life knowledge at the bottom. Against this background, we consider thinking about "periphery" as a metaphor or Denkfigur to be beneficial in comparison to "concept," whose elaboration is a notoriously difficult and seemingly never-ending task. Moreover, representations such as "analytical value" or "analytical range of concepts" as well as "analysis," "description," or "thick description" are imaginations created under specific circumstances, derived from specific social structures and sets of practices of knowledge production that are governed by particular interests and rules. Such representations are what Donna Haraway termed "situated knowledges."

Take this issue's articles for example. Although admittedly unintended, our result is an issue, where, in most sections, the authors are in one way or another linked to the editors, be it through PhD supervisors, close colleagues or the same alma mater. This means that the knowledge represented in this issue cannot be assessed adequately without taking into consideration the various and overlapping "master-disciple" and other social relations. Equally unintended but just as relevant, our issue is a compilation of three generations of social science scholarshipfrom Professor Emeritus to doctoral students. The ways in which our authors do research is influenced not only by their disciplinary background, but also by the politics of knowledge production of their time and, in many ways, by the different "turns" (be it the spatial turn, the cultural turn, the relativist turn, or the interpretive turn) in postmodern social sciences.

Not surprisingly, epistemological positions, logics of inquiry, arguments, vocabulary/terminology, and modes of repre- senting knowledge vary between articles, and perhaps, this is what constitutes the value of our issue: It does not merely discuss the journey of "periphery" through space and time. It also represents that very journey. 


\section{Notes}

1 Some claim the term has been first used in 1902 by an American, Captain Alfred Thayer Mahan (Lockman 98). Others assert an earlier use of the term by a British officer, General Sir Thomas Edward Gordon, in 1900 (Koppes 95).

2 We say "less" because it is us, two Europe-based editors, who use these labels.

${ }^{3}$ See the contribution by Elsenhans in this issue.

4 Dependency and WST also find an echo in current debates of German human geography, political science and planning studies dealing with "rural peripheries," "shrinking cities" and "urban fragmentation." See Belina, Best, and Naumann; Bernt Kühn and Bernt.

5 These reflections are an outcome of discussions with our colleagues of the research network "ReConfigurations. History, Remembrance and

Transformation Processes in the Middle East and North Africa"; a special thanks to Laura Ruiz de Elvira and

Christoph Schwarz.

\section{Works Cited}

Barth, Fredrik. "An Anthropology of Knowledge." Current Anthropology 43.1 (2002): 1-11. Print.

Amin, Samir. Unequal Development: An Essay on the Social Formation of Peripheral Capitalism. Harvester: Brighton, 1976. Print.

Augustin, Anne-Lind Amira. "Aden: Vom Zentrum zur Peripherie? Südarabische Jugendliche leisten Widerstand." Jugendbewegungen: Städtischer Widerstand und Umbrüche in der arabischen Welt. Ed. Jörg Gertel and Rachid Ouaissa. Bielefeld transcript, 2014. 246-67. Print.

Ayeb, Habib. "Social and Political Geography of the Tunisian Revolution: The Alfa Grass Revolution." Review of African Political Economy 38 (2011): 473-85. Print.

Belina, Bernd, Ulrich Best, and Matthias Naumann. "Critical Geography in Germany: From Exclusion to Inclusion via Internationalisation." Social Geography 4.1 (2009): 47-58. Print.
Bernt, Matthias. "Partnerships for Demolition: The

Governance of Urban Renewal in East Germany's Shrinking Cities." International Journal of Urban and Regional Research 33.3 (2009): 754-69. Print.

Blumberg, Rae L. "Income under Female versus Male Control: Hypotheses from a Theory of Gender Stratification and Data from the Third World." Journal of Family Issues 9.1 (1988): 51-84. Print.

Bouziane, Malika, Cilja Harders, and Anja Hoffmann, eds. Local Politics and Contemporary Transformations in the Arab World: Governance Beyond the Centre. Basingstoke: Palgrave Macmillan, 2013.

Entessar, Nader. Kurdis Ethnonationalism. Boulder,

Colorado: Lynne Rienner, 1992 Print

Fischer-Tahir, Andrea.

"Representations of

Peripheral Space in Iraq Kurdistan: The Case of the Qaradagh District Centre."

Études Rurales 186 (2011): 117-30. Prin
Fischer-Tahir, Andrea, and Matthias Naumann, eds.

Peripheralization: The Makin of Spatial Dependencies and Social Injustice. Berlin Springer VS, 2013. Print.

--. "Peripheralization as the Social Production of Spatial Dependencies and Injustice." Peripheralization. 9-26. Print.

Frank، André G. Capitalism and Underdevelopment in Latin America: Historical Studies of Chile and Brazil. New York: Monthly Review Press, 1967. Print.

Haraway, Donna. "Situated Knowledges: The Science Question in Feminism and the Privilege of Partial

Perspective." Feminist Studies 14.3 (1988): 575-99. Print

Harvey, David. The Limits to Capital. London: Verso, 1999. Print.

Kay, Cristóba. Latin American Theories of Development and Underdevelopment. London: Routledge, 1989. Print.

Koppes, Clayton R. "Captain Mahan, General Gordon

and the Origins of the Term 'Middle East'"' Middle Eastern Studies 12.1 (1976): 95-8. Print.
Kühn, Manfred, and Matthias Bernt. "Peripheralization and Political Power: Theoretical Debates." Peripheralization. 302-17. Print.

Lefebvre, Henri. The Production of Space. Oxford: Blackwell, 1991. Print.

Lockman, Zachary. Contending Visions of the Middle East: The History and Politics of Orientalism. 2nd ed. Cambridge: Cambridge UP, 2004. Print.

Massey, Doreen. Spatial Divisions of Labour: Social Relations and the Geography of Production. London: Macmillan, 1995. Print.

Mies, Maria. Patriarchy and Accumulation on a WorldScale. London: Zed Books, 1986. Print.

Prebisch, Raúl. The Economic Development of Latin

America and Its Principal

Problems. New York: United Nations Department of Economic Affairs, 1950. Print. 
$\rightarrow$ Quijano, Aníbal. "Imperialism and Marginality in Latin America." Development in Theory and Practice: Latin American Perspectives. Ed. Ronald H. Chilcote. Lanham: Rowman \& Littlefield, 2003. 155-59. Print.

Ruiz de Elvira, Laura, and Tina Zintl. "The End of the Ba'thist Social Contract in Bashar al-Asad's Syria: Reading

Sociopolitical Transformations through Charities and Broader Benevolent

Activism." International Journal of Middle East Studies 46.2 (2014): 329-49. Web. 10 Oct. 2015.

Schetter, Conrad, and Rainer Glassner. "The Peripherization of the Center: 'Warlordism' in Afghanistan." Afghanistan 1979-2009: In the Grip of the Conflict. Ed. Middle East Institute. Washington, DC: Middle East Institute, 2009 118-21. Web. 10 Oct. 2015.

Senghaas, Dieter. Peripherer Kapitalismus: Analysen über Abhängigkeit

und Unterentwicklung.

Frankfurt/M.: Suhrkamp, 1974. Print.
Smith, Neil. Uneven

Development: Nature, Capital

and the Production of Space.

Oxford: Basil Blackwell, 1984.

Print.

Wallerstein, Immanuel. The

Modern World-System I:

Capitalist Agriculture and

the Origins of the European

World-Economy in the

Sixteenth Century. New York;

London: Academic Press,

1974. Print.

Ward, Kathryn B. Women in the World-System: Its Impact on Status and Fertility. New York: Praeger, 1984. Print.

Wedeen, Lisa. Peripheral Visions: Publics, Power, and Performance in Yemen.

Chicago: $U$ of Chicago $P$ 2008. Print. 